TRANSATLANTIC SPECULATIONS 



\section{TRANSATLANTIC SPECULATIONS}

Globalization and the Panics of 1873

HANNAH CATHERINE DAVIES

Columbia University Press

New York 
Columbia University Press

Publishers Since 1893

New York Chichester, West Sussex

cup.columbia.edu

Copyright (c) 2018 Columbia University Press

All rights reserved

Library of Congress Cataloging-in-Publication Data

Names: Davies, Hannah Catherine, author.

Title: Transatlantic speculations : globalization and the panics of 1873 / Hannah Catherine Davies.

Description: New York : Columbia University Press, [2018] | Includes bibliographical references and index.

Identifiers: LCCN 2018012327 | ISBN 9780231185561 (cloth : alk. paper) |

ISBN 9780231546218 (e-book)

Subjects: LCSH: Depressions-1873-United States | Depressions-1873-Europe | Speculation-History-19th century. | Journalism, Commercial-19th century. Classification: LCC HB3717 1873 .D38 2018 | DDC 330.9/034-dc23

LC record available at https://lccn.loc.gov/2018012327

Columbia University Press books are printed on permanent and durable acid-free paper. Printed in the United States of America

Cover design: Noah Arlow 